\title{
HUBUNGAN USIA BALITA DAN SANITASI FISIK RUMAH DENGAN KEJADIAN ISPA DI DESA TUMAPEL KABUPATEN MOJOKERTO TAHUN 2017
}

\author{
Maulidiyah Dwi Azti Putri ${ }^{1)}$, Retno Adriyani ${ }^{2)}$ \\ ${ }^{1}$ Dinas Kesehatan Kabupaten Mojokerto, Kabupaten Mojokerto \\ ${ }^{2}$ Departemen Kesehatan Lingkungan, Fakultas Kesehatan Masyarakat, Universitas Airlangga \\ Alamat Korespondensi: Maulidiyah Dwi Azti Putri \\ E-mail: aztiputri207@gmail.com
}

\begin{abstract}
ARI is a major killer of toddlers the world, more than AIDS, malaria, and measles combined. In the world, every year estimated more than 2 million toddlers died because of ARI (Unicef/WHO, 2006). This research was an observational study with cross sectional design. The population in this research were children was 50 toddlers. Sampling using cluster random sampling technique. The dependent variable was ARI in toddlers in Tumapel Village, Mojokerto District. The independent variables were toddlers characteristics and the physical sanitary home. The methods used to take primary data were interview with questionnaire, observation, and measurement. While secondary data collection was from the device of Tumapel Village, Dlanggu Public Health Center, and the Health Departemen of Mojokerto. This research used logistic regression with confidence interval $0,05(\alpha=5 \%)$. The result showed there were 2 variables that had significant correlation with ARI, they were age of toddlers $(p=0,013)$ and the physical sanitary home $(p=0,015)$. The results of temperature and humidity measurement were not correlated, moreover, $P M_{2,5}$ measurement in the respondents' house exceed the limit sets by the Ministry of Health (Permenkes No. 1077 Tahun 2011). The conclusion of this research was age of the toddlers and the physical sanitary home had correlation with ARI. It was recommended to improve toddlers immunity through giving the balance diet and to improve environmental health with closing house ventilation in the day and afternoon so the concentration of $P M_{2,5}$ in the house can be decreased to lower the risk of ARI.
\end{abstract}

Keywords: the age of toddlers, the physical sanitary home, and incidence of ARI

\begin{abstract}
ABSTRAK
ISPA adalah pembunuh utama anak balita di dunia, lebih banyak dibandingkan dengan gabungan penyakit AIDS, malaria dan campak. Di dunia setiap tahun diperkirakan lebih dari 2 juta anak balita meninggal karena ISPA (UNICEF/WHO,2006). Penelitian ini merupakan penelitian observasional dengan desain cross sectional. Populasi pada penelitian ini adalah anak balita dengan besar sampel sebanyak 50 anak balita. Pengambilan sampel menggunakan teknik cluster random sampling. Variabel terikat adalah kasus ISPA pada anak balita di Desa Tumapel Kabupaten Mojokerto. Variabel bebas adalah karakteristik anak balita dan sanitasi fisik rumah. Metode pengambilan data primer yaitu melakukan wawancara dengan kuesioner, observasi, dan pengukuran. Pengumpulan data sekunder dari Ponkesdes, Puskesmas Dlanggu, dan Dinas Kesehatan Kabupaten Mojokerto. Penelitian ini menggunakan uji statistik regresi logistik dengan derajat kepercayaan $0,05(\alpha=5 \%)$. Hasil penelitian menunjukkan terdapat 2 variabel yang memiliki hubungan signifikan dengan kejadian ISPA yaitu karakteristik umur anak balita $(p=0,013)$ dan sanitasi fisik rumah $(p=0,015)$. Hasil pengukuran suhu udara dan kelembapan tidak memenuhi syarat, serta pengukuran $\mathrm{PM}_{2,5}$ dalam rumah responden melebihi batas maksimal Peraturan Menteri Kesehatan no 1077 tahun 2011. Kesimpulannya adalah karakteristik umur balita dan sanitasi fisik rumah memiliki hubungan dengan kasus ISPA. Disarankan agar ada upaya untuk meningkatkan daya tahan tubuh balita dengan memberikan makanan dengan menu gizi seimbang dan meningkatkan kesehatan lingkungan rumah yaitu dengan menutup ventilasi rumah ketika siang dan sore hari agar konsentrasi $\mathrm{PM}_{2,5}$ dapat berkurang di dalam rumah sehingga dapat menurunkan risiko terjadinya ISPA.
\end{abstract}

Kata kunci: usia anak balita, sanitasi fisik rumah, dan kejadian ISPA 


\section{PENDAHULUAN}

Kualitas udara di dalam rumah sangat erat kaitannya dengan sanitasi fisik rumah dan berpengaruh terhadap kesehatan penghuninya terutama pada anak balita. Apabila lingkungan rumah tidak sehat maka akan memudahkan terjadinya berbagai penyakit. Penularan jenis penyakit berbasis lingkungan salah satunya yaitu Infeksi Saluran Pernapasan Akut (ISPA). Sanitasi fisik rumah yang tidak memenuhi syarat kesehatan dapat menjadi lingkungan yang tepat bagi pertumbuhan dan perkembangbiakan bakteri penyebab ISPA pada anak balita. Luas ventilasi yang tidak memenuhi persyaratan dapat memengaruhi kondisi kelembapan di dalam ruangan, begitu pula kepadatan hunian di dalam suatu ruangan dapat mempercepat penularan penyakit (Putri, 2017).

Menurut laporan EPA (2017) bahwa tingkat konsentrasi pencemaran udara outdoor lebih tinggi yaitu 2-5 kali dibandingkan tingkat konsentrasi pencemaran udara indoor. Jika konsentrasi $\mathrm{PM}_{2,5}$ di dalam ruangan yang melebihi batas maksimal akan mempermudah terjadinya ISPA pada anak balita, hal ini dikarenakan adanya konsentrasi $\mathrm{PM}_{2,5}$ dapat masuk ke dalam saluran pernapasan bagian bawah yaitu alveoli sehingga berisiko terjadi ISPA. Terdapat beberapa kategori penilaian sanitasi fisik rumah yaitu baik, cukup, dan kurang. Apabila sanitasi fisik rumah baik maka anak balita terkena ISPA menurun dan apabila sanitasi fisik rumah kurang maka risiko anak balita terkena ISPA semakin tinggi, serta terdapat hubungan antara sanitasi fisik rumah dengan kasus ISPA pada anak balita (Yusup, 2005; Iswarini, 2006).

Berdasarkan hasil data pemeriksaan sanitasi fisik rumah sehat di Kabupaten Mojokerto pada tahun 2015, rumah yang dinyatakan sehat sebesar $62,13 \%$ dari jumlah rumah yang diperiksa (Dinkes Kabupaten Mojokerto, 2015). Hal ini menunjukkan penurunan jumlah rumah sehat pada tahun 2014 sebesar 74,50\% dan pada tahun 2013 jumlah rumah sehat sebesar $72,43 \%$.

ISPA yang diawali dengan panas disertai salah satu atau lebih gejala demam, pilek, sakit tenggorokan, dan batuk kering atau berdahak yang merupakan gejala awal dari terjadinya infeksi (Badan Penelitian dan Pengembangan Kesehatan, 2013). Penyakit ISPA sering terjadi pada anak balita. Rentang waktu anak terkena penyakit batuk dan pilek diperkirakan 3-6 kali per tahun, artinya seorang balita ratarata dapat serangan batuk dan pilek sebanyak 3-6 kali dalam satu tahun (Widoyono, 2011). ISPA adalah pembunuh utama anak balita di dunia, jika dibandingkan dengan gabungan penyakit AIDS, malaria dan campak. Di dunia setiap tahun diperkirakan lebih dari 2 juta anak balita meninggal karena ISPA. Pneumonia merupakan salah satu kasus ISPA yang banyak dijumpai. Penyebab utama pneumonia pada anak balita yaitu bakteri patogen streptococcus pneumoniae (UNICEF/ WHO,2006). Anak balita berjenis kelamin laki-laki lebih berisiko terkena ISPA dibandingkan anak balita yang berjenis kelamin perempuan. Terdapat hubungan antara karakteristik anak balita menurut jenis kelamin dengan kasus ISPA (Iskandar dkk 2015; Rasyid, 2013; Ranantha dkk 2012).

Pola asuh anak yang tidak memadai akan memengaruhi status gizi balita. Hal ini dapat disebabkan karena kurangnya penge-tahuan, keterampilan ibu mengenai gizi serta imunisasi, dan pelayanan kesehatan dasar yang tidak memadai. Anak balita dengan keadaan gizi buruk dan gizi kurang lebih mudah terkena infeksi dibandingkan dengan balita dengan gizi baik, hal ini disebabkan lemahnya daya tahan tubuh balita. Anak balita dengan status gizi kurang lebih berisiko terkena ISPA dibandingkan anak balita dengan status gizi baik. Terdapat hubungan antara status gizi anak balita dengan kasus ISPA (Surdirman, 2003; Febrianto dkk, 2014; Nugraheni, 2014; Widia, 2017). 
Anak balita memiliki kerentanan terhadap penyakit, salah satunya adalah penyakit ISPA, dikarenakan daya tahan tubuh yang masih lemah dibandingkan orang dewasa. Penyakit ISPA pada balita dapat dicegah dengan melakukan imunisasi lengkap sejak usia 0-12 bulan dan mendapatkan ASI eksklusif sejak usia 0-6 bulan tanpa memberikan makanan tambahan kepada anak balita. Anak balita dengan status imunisasi tidak lengkap lebih berisiko terkena ISPA dibandingkan anak balita dengan status imunisasi lengkap. Terdapat hubungan antara status imunisasi dengan kasus ISPA pada anak balita (Adelina, 2014; Rasyid, 2013). Anak balita yang tidak mendapatkan ASI eksklusif lebih berisiko terkena ISPA dibandingkan anak balita yang mendapatkan ASI eksklusif. Terdapat hubungan pemberian ASI eksklusif dengan kasus ISPA pada anak balita (Abbas dkk, 2010; Widarini dkk, 2010; Rasyid, 2013).

Data kasus ISPA non pneumonia Desa Tumapel pada tahun 2014 yaitu sebanyak 249 kasus dari jumlah populasi 124 anak balita. Pada tahun 2014, kasus ISPA non pneumonia mengalami peningkatan kasus hingga $100 \%$ dari jumlah anak balita di Desa Tumapel. Pada tahun 2015 data kasus ISPA non pneumonia yaitu 228 kasus dari jumlah populasi 133 anak balita. Pada tahun 2015 kasus ISPA non pneumonia mengalami penurunan jumlah kasus ISPA dibandingkan pada tahun 2014, tetapi jumlah kasus ISPA non pneumonia di Desa Tumapel masih terbilang tinggi dikarenakan anak balita menderita ISPA 24 kali dalam 1 tahun. Adanya permasalahan tingginya kasus ISPA non pneumonia dan kondisi sanitasi fisik rumah warga menjadi latar belakang untuk melakukan penelitian mengenai hubungan karakteristik dan sanitasi fisik rumah dengan kejadian ISPA pada balita di Desa Tumapel Kabupaten Mojokerto.

\section{METODE PENELITIAN}

Jenis penelitian ini adalah penelitian observasional dimana peneliti hanya melakukan pengamatan langsung terhadap variabel yang diteliti tanpa memberikan perlakuan. Desain penelitian yang digunakan adalah cross sectional. Dalam penelitian cross sectional dilakukan pengamatan variabel yang diteliti secara serentak dan pada saat yang sama.

Populasi penelitian adalah seluruh anak balita yang tinggal di Desa Tumapel pada bulan Juni tahun 2017 yaitu 103 anak balita. Sampel penelitian adalah anak balita yang tinggal di Desa Tumapel, dengan kriteria inklusi yaitu anak balita harus didampingi oleh orang tua atau anggota keluarga yang lebih tua yang tinggal serumah dengan responden, dan anak balita tidak memiliki riwayat penyakit bawaan sejak lahir. Besar sampel penelitian adalah 50 anak balita yang diperoleh dari hasil perhitungan besar sampel menggunakan rumus Lemeshow dkk (1997) dengan tingkat kesalahan 10\%, adapun rumus yang digunakan adalah sebagai berikut:

$\mathrm{n}=\frac{\mathrm{N}(\mathrm{Z}: 1-\alpha / 2) 2 \mathrm{p} \cdot \mathrm{q}}{\mathrm{d} 2(\mathrm{~N}-1)+(\mathrm{Z} 1-\alpha / 2) 2 \mathrm{p} \cdot \mathrm{q}}$

Keterangan:

$\mathrm{n} \quad=$ Besaran sampel

$1-\mathrm{a} / 2=$ Selang kepercayaan 95\% (maka

$\left.\mathrm{Z}_{1-\mathrm{a} / 2}=1,96\right)$

$\mathrm{p}=$ Perkiraan proporsi (prevalensi) penyakit (atau paparan) pada populasi. Apabila tidak diketahui maka digunakan p: 0,5 untuk menghasilkan nilai $\mathrm{n}$ terbesar (Notoatmodjo, 2010)

$\mathrm{q}=1-\mathrm{p}$

$\mathrm{N} \quad=$ Besaran populasi

$\mathrm{d}=$ Presisi absolute yang diinginkan pada kedua sisi proporsi populasi, yaitu sebesar 5\%

Cara penentuan sampel pada penelitian ini dilakukan dengan 
menggunakan teknik cluster random sampling, yaitu pengambilan sampel dengan cara pengelompokan berdasarkan wilayah atau lokasi populasi. Sampel dikumpulkan berdasarkan masing-masing kelompok dengan perhitungan menggunakan rumus Nursalam (2013) sebagai berikut:

$n 1=\frac{N 1}{N} x n$

Keterangan:

$\mathrm{N} \quad=$ Besar seluruh populasi

$\mathrm{N} 1=$ Besar populasi tiap RT

$\mathrm{n} \quad=$ Besar seluruh sampel

$\mathrm{n} 1=$ Besar sampel tiap RT

Desa Tumapel memiliki 3 Dusun yaitu Dusun Tarukan (RW1), Dusun Dempel (RW2), dan Dusun Seduri (RW3). Tiga RW terdapat 7 RT di Desa Tumapel. Pembagian besar sampel berdasarkan wilayah atau lokasi. Pembagian besar sampel berdasarkan RT diantaranya RT 1 terdapat 7 sampel anak balita, RT 2 terdapat 8 sampel anak balita, RT 3 terdapat 8 sampel anak balita, RT 4 terdapat 6 sampel anak balita, RT 5 terdapat 5 sampel anak balita RT 6 terdapat 8 sampel anak balita, RT 7 terdapat 8 sampel anak balita, dan RT 8 terdapat 8 sampel anak balita. Prosedur acak dilakukan dengan metode lotre technique. Penelitian ini dilakukan pada bulan Januari-Juni 2017. Lokasi penelitian adalah di Desa Tumapel Kecamatan Dlanggu Kabupaten Mojokerto.

Cara pengumpulan data dengan melakukan wawancara, observasi, dan pengukuran. Pengumpulan data mengenai kejadian ISPA pada anak balita dan karakteristik anak balita (umur, jenis kelamin, status gizi, ASI eksklusif, dan imunisasi) dilakukan dengan mewawancarai orang tua anak balita dan melihat buku KMS/KIA. Wawancara dilakukan dengan menggunakan kuesioner dengan didampingi oleh bidan dan kader Desa Tumapel. Cara pengumpulan data sanitasi fisik rumah dilakukan dengan melakukan observasi secara langsung menggunakan check list yang disusun sesuai dengan pedoman penilaian rumah sehat dan melakukan pengukuran sanitasi fisik rumah (suhu, kelembapan, pencahayaan, luas ventilasi, kepadatan hunian, dan $\mathrm{PM}_{2,5}$ ). Pengukuran sanitasi fisik rumah dengan menggunakan alat thermohygrometer untuk mengukur suhu serta kelembapan, lux meter untuk mengukur pencahayaan, EPAM 5000 untuk mengukur kadar debu $\mathrm{PM}_{2,5}$ dan roll meter untuk mengukur luas ventilasi dan kepadatan hunian. Observasi dan pengukuran sanitasi fisik rumah ini didampingi oleh laboran Fakultas Kesehatan Masyarakat Universitas Airlangga.

Hasil pengukuran sanitasi fisik rumah kemudian dibandingkan dengan standar peraturan terkait dan dikategorikan menjadi 2 (memenuhi syarat dan tidak memenuhi syarat). Data pendukung di dapat dari Puskesmas Dlanggu, Ponkesdes Desa Tumapel dan Dinas Kesehatan Kabupaten Mojokerto sebagai data sekunder. Data yang diperoleh diolah menggunakan uji statistika yaitu uji regresi logistik dengan melihat derajat kemaknaan hubungan apabila nilai $p$ kurang dari 0,05 ( $p$ kurang dari $\alpha$ ) yang artinya terdapat hubungan signifikan. Penelitian ini telah memperoleh persetujuan dari komisi etik penelitian kesehatan Fakultas Kesehatan Masyarakat Universitas Airlangga dengan no : 181-KEPK pada tanggal 04 Mei 2017.

\section{HASIL}

\section{Karakteristik Anak Balita}

Variabel yang digunakan untuk mengidentifikasi karakteristik anak balita adalah umur, jenis kelamin, imunisasi, ASI eksklusif, dan status gizi dalam bentuk kuesioner. Hasil analisis karakteristik anak balita disajikan dalam Tabel 1 sebagai berikut: 
Tabel 1. Karakteristik Anak Balita di Desa Tumapel, Kecamatan Dlanggu, Kabupaten Mojokerto 2017

\begin{tabular}{lrr}
\hline Karakteristik & \multicolumn{2}{c}{ Total } \\
\cline { 2 - 3 } Responden & n & \% \\
\hline Umur & 24 & 48,0 \\
1-2 tahun & 9 & 18,0 \\
2-3 tahun & 12 & 24,0 \\
3-4 tahun & 5 & 10,0 \\
4-5 tahun & & 46,0 \\
\hline Jenis Kelamin & 23 & 54,0 \\
Laki-laki & 27 & \\
Perempuan & & 98,0 \\
Imunisasi & & 2,0 \\
Lengkap & 49 & \\
Tidak & 1 & 76,0 \\
Lengkap & & 24,0 \\
\hline ASI eksklusif & 38 & \\
Ya & 12 & 4,0 \\
Tidak & & 94,0 \\
\hline Status gizi & 2 & 2,0 \\
Lebih & 47 & \\
Baik & 1 & \\
Kurang & &
\end{tabular}

Tabel 1 menyatakan bahwa jumlah distribusi umur anak balita terbanyak adalah 1-2 tahun yaitu 48,0\%. Kasus ISPA sering terjadi pada anak balita usia 1 - 2 tahun. Jenis kelamin anak balita diketahui sebagian besar berjenis kelamin perempuan sebesar $54,0 \%$.

Karakteristik anak balita menurut kelengkapan imunisasi diperoleh bahwa sebagian besar anak balita di Desa Tumapel telah mendapatkan imunisasi yang lengkap (98,0\%). Terdapat 1 anak balita yang tidak mendapatkan imunisasi yang lengkap dikarenakan ketika ada posyandu anak balita sedang sakit sehingga tidak dapat mengikuti kegiatan posyandu serta tidak mendapatkan imunisasi.

Karakteristik anak balita menurut ASI eksklusif diperoleh sebagian besar anak balita mendapatkan ASI eksklusif (76,0\%). Anak balita pada usia 0-6 bulan hanya diberikan ASI tanpa tambahan makanan ataupun susu formula. Masih terdapat beberapa anak balita yang tidak mendapatkan ASI eksklusif dikarenakan gangguan kesehatan yang dialami oleh ibu kandung dari anak balita sehingga sang ibu tidak dapat memberikan ASI eksklusif.

Karakteristik anak balita menurut status gizi diketahui bahwa sebagian besar anak balita memiliki status gizi baik $(94,0 \%)$. Terdapat 1 anak balita yang berstatus gizi kurang, hal ini dikarenakan anak balita tersebut susah makan, terutama dalam mengkonsumsi sayuran serta buahbuahan.

\section{Sanitasi fisik rumah}

Variabel untuk mengidentifikasi sanitasi fisik rumah menggunakan panduan observasi penilaian rumah sehat dan dibandingkan dengan Permenkes 1077 Tahun 2011 tentang Pedoman Penyehatan Udara dalam Ruang Rumah, dengan 6 variabel. Variabel pengukuran sanitasi fisik rumah tersebut disesuaikan dengan kebutuhan penelitian yaitu suhu, kelembapan, pencahayaan, luas ventilasi, kepadatan hunian, dan $\mathrm{PM}_{2,5}$. Hasil analisis mengenai sanitasi fisik rumah di Desa Tumapel disajikan dalam Tabel 2 sebagai berikut:

Tabel 2. Distribusi Pengukuran Sanitasi Fisik Rumah di Desa Tumapel Kabupaten Mojokerto Tahun 2017.

\begin{tabular}{lcccc}
\hline \multirow{2}{*}{$\begin{array}{c}\text { Sanitasi } \\
\text { Fisik } \\
\text { Rumah }\end{array}$} & \multicolumn{2}{c}{$\begin{array}{c}\text { Memenuh } \\
\text { i Syarat }\end{array}$} & \multicolumn{2}{c}{$\begin{array}{c}\text { Tidak } \\
\text { Memenuh } \\
\text { i Syarat }\end{array}$} \\
\cline { 2 - 5 } & n & \% & n & \% \\
\hline Suhu & 28 & 56,0 & 22 & 44,0 \\
\hline $\begin{array}{l}\text { Kelembapa } \\
\text { n }\end{array}$ & 12 & 24,0 & 38 & 76,0 \\
\hline $\begin{array}{l}\text { Pencahayaa } \\
\text { n }\end{array}$ & 37 & 74,0 & 13 & 26,0 \\
\hline $\begin{array}{l}\text { Luas } \\
\text { ventilasi }\end{array}$ & 37 & 74,0 & 13 & 26,0 \\
\hline $\begin{array}{l}\text { Kepadatan } \\
\text { hunian }\end{array}$ & 46 & 92,0 & 4 & 8,0 \\
\hline
\end{tabular}


Tabel 2 menyatakan bahwa sanitasi fisik rumah pada pengukuran suhu udara dalam ruang diketahui bahwa sebagian besar rumah telah memenuhi syarat (56,0\%) sesuai dengan Permenkes 1077 Tahun 2011 tentang Pedoman Penyehatan Udara dalam Ruang.

Sanitasi fisik rumah pada pengukuran kelembapan dalam ruang diketahui bahwa sebagian besar rumah tidak memenuhi syarat $(76,0 \%)$. Sanitasi fisik rumah pada pengukuran pencahayaan dalam ruang diketahui bahwa sebagian besar rumah responden telah memenuhi syarat $(74,0 \%)$.

Sanitasi fisik rumah pada pengukuran luas ventilasi dalam rumah diketahui bahwa sebagian besar rumah telah memenuhi syarat $(74,0 \%)$. Sanitasi fisik rumah pada pengukuran kepadatan hunian dalam rumah diketahui bahwa sebagian besar memenuhi syarat $(92,0 \%)$.

PM2,5. Hasil analisis pengukuran konsentrasi debu $\mathrm{PM}_{2,5}$ pada rumah responden diketahui bahwa seluruh rumah tidak memenuhi syarat sesuai dengan Permenkes 1077 Tahun 2011 tentang Pedoman Penyehatan Udara dalam Ruang.

\section{Kasus ISPA pada balita}

Kasus ISPA pada anak balita di Desa Tumapel Kabupaten Mojokerto pada bulan Mei Tahun 2017 disajikan dalam Tabel 3 sebagai berikut:

Tabel 3. Distribusi Kasus ISPA pada Anak Balita di Desa Tumapel Kecamatan Dlanggu Kabupaten Mojokerto Tahun 2017

\begin{tabular}{lcc}
\hline \multirow{2}{*}{ Kasus ISPA } & \multicolumn{2}{c}{ Total } \\
\cline { 2 - 3 } & $\mathbf{n}$ & $\mathbf{\%}$ \\
\hline Ya & 36 & 72,0 \\
\hline Tidak & 14 & 28,0 \\
\hline \multicolumn{1}{c}{ Total } & 50 & 100,0 \\
\hline
\end{tabular}

Tabel 3 menunjukkan sebagian besar responden yang pernah menderita ISPA dalam rentang waktu 3 bulan terakhir $(72,0 \%)$.

\section{Hubungan antara karakteristik dengan kasus ISPA pada anak balita}

Sub variabel yang digunakan untuk menganalisis hubungan karakteristik anak balita dengan kasus ISPA adalah umur, jenis kelamin, imunisasi, ASI eksklusif, dan status gizi.

\section{Umur}

Tabel 4. Hubungan Karakteristik Umur dengan Kasus ISPA pada Anak Balita di Desa Tumapel Kabupaten Mojokerto Tahun 2017

\begin{tabular}{cccc}
\hline \multirow{2}{*}{ Umur } & \multicolumn{2}{c}{$\begin{array}{c}\text { Kasus ISPA pada } \\
\text { Anak Balita }\end{array}$} & \multirow{2}{*}{ Total } \\
\cline { 2 - 3 } & ISPA & $\begin{array}{c}\text { Tidak } \\
\text { ISPA }\end{array}$ \\
\hline 1-2 Tahun & 13 & 11 & 24 \\
\cline { 2 - 3 } & $26,0 \%$ & $22,0 \%$ & $48,0 \%$ \\
\hline 2-3 Tahun & 7 & 2 & 9 \\
\cline { 2 - 3 } & $14,0 \%$ & $4,0 \%$ & $18,0 \%$ \\
\hline 3-4 Tahun & 11 & 1 & 12 \\
\cline { 2 - 3 } & $22,0 \%$ & $2,0 \%$ & $24,0 \%$ \\
\hline 4-5 Tahun & 5 & 0 & 5 \\
\cline { 2 - 3 } & $10,0 \%$ & $0,0 \%$ & $10,0 \%$ \\
\hline Total & 36 & 14 & 50 \\
\cline { 2 - 3 } & $72,0 \%$ & $28,0 \%$ & $100,0 \%$ \\
\hline & $\mathrm{p}-$ value $=0,013<\alpha$ \\
\hline
\end{tabular}

Hasil analisis hubungan antara karakteristik anak balita menurut umur dengan data kasus ISPA disajikan dalam Tabel 4. Berdasarkan hasil analisis, diperoleh bahwa nilai $\mathrm{p}$ untuk variabel umur sebesar 0,013 atau nilai $p$ kurang dari $0,05 \quad(p \quad$ kurang dari $\alpha)$ yang artinya,terdapat hubungan signifikan antara karakteristik umur dengan kasus ISPA pada anak balita di Desa Tumapel Kabupaten Mojokerto. Mayoritas umur anak balita yang terkena ISPA adalah 1-2 tahun sebesar 26,0\%. Anak balita yang tidak terkena ISPA berusia 4-5 tahun sebesar $28,0 \%$. Daya tahan tubuh anak 
balita yang berusia 4-5 tahun relatif sudah baik.

\section{Jenis kelamin}

Hasil analisis hubungan antara karakteristik anak balita menurut jenis kelamin dengan kasus ISPA disajikan dalam Tabel 5 sebagai berikut:

Berdasarkan hasil analisis diperoleh bahwa nilai $p$ untuk variabel jenis kelamin sebesar 0,764 atau nilai $p$ lebih dari 0,05 ( $p$ kurang dari $\alpha$ ) artinya tidak ada hubungan signifikan antara jenis kelamin dengan kasus ISPA pada anak balita di Desa Tumapel Kabupaten Mojokerto.

Tabel 5. Hubungan Karakteristik Jenis Kelamin dengan Kasus ISPA pada Anak Balita di Desa Tumapel Kabupaten Mojokerto Tahun 2017

\begin{tabular}{|c|c|c|c|}
\hline \multirow{2}{*}{$\begin{array}{c}\text { Jenis } \\
\text { Kelamin }\end{array}$} & \multicolumn{2}{|c|}{$\begin{array}{c}\text { Kasus ISPA } \\
\text { pada Anak } \\
\text { Balita } \\
\end{array}$} & \multirow[t]{2}{*}{ Total } \\
\hline & ISPA & $\begin{array}{l}\text { Tidak } \\
\text { ISPA }\end{array}$ & \\
\hline \multirow[t]{2}{*}{ Laki-laki } & 18 & 5 & 23 \\
\hline & $36,0 \%$ & $10,0 \%$ & $46,0 \%$ \\
\hline \multirow[t]{2}{*}{ Perempuan } & 18 & 9 & 27 \\
\hline & $36,0 \%$ & $18,0 \%$ & $54,0 \%$ \\
\hline \multirow[t]{2}{*}{ Total } & 36 & 14 & 55 \\
\hline & $72,0 \%$ & $28,0 \%$ & $100,0 \%$ \\
\hline \multicolumn{4}{|c|}{$\mathrm{p}$-value $=0,764>\alpha$} \\
\hline
\end{tabular}

\section{Imunisasi}

Berdasarkan hasil analisis diperoleh bahwa nilai $\mathrm{p}$ untuk variabel imunisasi sebesar 0,272 atau nilai $p$ lebih dari 0,05 ( $p$ lebih dari $\alpha$ ) yang artinya tidak ada hubungan signifikan antara karakteristik imunisasi dengan kasus ISPA pada anak balita di Desa Tumapel Kabupaten Mojokerto. Hasil analisis hubungan antara karakteristik imunisasi anak balita dengan kasus ISPA disajikan dalam Tabel 6 sebagai berikut:
Tabel 6. Hubungan Karakteristik Imunisasi dengan Kasus ISPA pada Anak Balita di Desa Tumapel Kabupaten Mojokerto Tahun 2017

\begin{tabular}{lccc}
\hline \multirow{2}{*}{ Imunisasi } & \multicolumn{2}{c}{$\begin{array}{c}\text { Kasus ISPA } \\
\text { pada Anak } \\
\text { Balita }\end{array}$} & Total \\
\cline { 2 - 3 } & ISPA & $\begin{array}{c}\text { Tidak } \\
\text { ISPA }\end{array}$ \\
\hline Lengkap & 36 & 13 & 49 \\
\cline { 2 - 3 } & $72,0 \%$ & $26,0 \%$ & $98,0 \%$ \\
\hline Tidak & 0 & 1 & 1 \\
Lengkap & $0,0 \%$ & $2,0 \%$ & $2,0 \%$ \\
\hline Total & 36 & 23 & 50 \\
\cline { 2 - 3 } & $72,0 \%$ & $28,0 \%$ & $100,0 \%$ \\
\hline & p-value $=0,272>\alpha$ \\
\hline
\end{tabular}

\section{ASI eksklusif}

Hasil analisis hubungan antara karakteristik anak balita menurut ASI eksklusif dengan kasus ISPA disajikan dalam Tabel 7 sebagai berikut:

Tabel 7. Hubungan Karakteristik ASI Eksklusif dengan Kasus ISPA pada Anak Balita di Desa Tumapel Kabupaten Mojokerto Tahun 2017

\begin{tabular}{lccc}
\hline \multirow{2}{*}{$\begin{array}{c}\text { ASI } \\
\text { Eksklusif }\end{array}$} & \multicolumn{2}{c}{$\begin{array}{c}\text { Kasus ISPA } \\
\text { pada Anak } \\
\text { Balita }\end{array}$} & \multirow{2}{*}{ Total } \\
\cline { 2 - 3 } & ISPA & $\begin{array}{c}\text { Tidak } \\
\text { ISPA }\end{array}$ \\
\hline Ya & 27 & 11 & 38 \\
\cline { 2 - 3 } & $54,0 \%$ & $22,0 \%$ & $76,0 \%$ \\
\hline Tidak & 9 & 3 & 12 \\
\hline Total & $18,0 \%$ & $6,0 \%$ & $24,0 \%$ \\
\cline { 2 - 3 } & 36 & 14 & 55 \\
\hline & $72,0 \%$ & $28,0 \%$ & $100,0 \%$ \\
\hline
\end{tabular}

Berdasarkan hasil analisis, diperoleh bahwa nilai $p$ untuk variabel ASI eksklusif sebesar 0,965 atau nilai $p$ lebih 
dari 0,05 ( $p$ lebih dari $\alpha$ ) yang artinya tidak ada hubungan signifikan antara karakteristik ASI eksklusif dengan kasus ISPA pada anak balita di Desa Tumapel Kabupaten Mojokerto.

\section{Status gizi}

Tabel 8. Hubungan Karakteristik Status Gizi dengan Kasus ISPA pada Anak Balita di Desa Tumapel Kabupaten Mojokerto Tahun 2017

\begin{tabular}{lccc}
\hline \multirow{2}{*}{$\begin{array}{c}\text { Status } \\
\text { Gizi }\end{array}$} & \multicolumn{2}{c}{$\begin{array}{c}\text { Kasus ISPA pada } \\
\text { Anak Balita }\end{array}$} & Total \\
\cline { 2 - 3 } & ISPA & $\begin{array}{c}\text { Tidak } \\
\text { ISPA }\end{array}$ & \\
\hline Lebih & 2 & 0 & 2 \\
\cline { 2 - 3 } & $4,0 \%$ & $0,0 \%$ & $4,0 \%$ \\
\hline Baik & 33 & 14 & 47 \\
\cline { 2 - 3 } & $66,0 \%$ & $28,0 \%$ & $94,0 \%$ \\
\hline Kurang & 1 & 0 & 1 \\
\cline { 2 - 3 } & $2,0 \%$ & $0,0 \%$ & $2,0 \%$ \\
\hline Total & 36 & 14 & 50 \\
\cline { 2 - 3 } & $72,0 \%$ & $28,0 \%$ & $100,0 \%$ \\
\hline & $\mathrm{p}-$ value $=0,237>\alpha$ \\
\hline
\end{tabular}

Hasil analisis hubungan antara karakteristik anak balita menurut status gizi dengan kasus ISPA disajikan dalam Tabel 8. Berdasarkan hasil analisis diperoleh bahwa nilai $p$ untuk variabel status gizi sebesar 0,237 atau nilai $p$ lebih dari 0,05 ( $p$ lebih dari $\alpha$ ). Hal ini berarti, tidak ada hubungan signifikan antara karakteristik status gizi dengan kasus ISPA pada anak balita di Desa Tumapel Kabupaten Mojokerto.

\section{Hubungan sanitasi fisik rumah dengan kasus ISPA pada anak balita}

Variabel sanitasi fisik rumah dikategorikan menjadi 3 kategori penilaian yaitu kategori baik, cukup, dan kurang. Hubungan sanitasi fisik rumah dengan kasus ISPA pada anak balita di Desa Tumapel disajikan pada Tabel 9 sebagai berikut:

Berdasarkan Tabel 9 diketahui bahwa mayoritas anak balita yang pernah mengalami ISPA dalam rentang waktu 3 bulan terakhir di Desa Tumapel termasuk sanitasi fisik rumah dalam kategori kurang. Jumlah rumah anak balita yang masuk dalam kategori sanitasi fisik rumah kurang sebesar 44,0\%. Mayoritas anak balita yang tidak mengalami ISPA dalam rentang waktu 3 bulan terakhir di Desa Tumapel termasuk sanitasi fisik rumah dalam kategori cukup sebesar 12,0\%.

Tabel 9. Hubungan Sanitasi Fisik Rumah dengan Kasus ISPA di Desa Tumapel Kabupaten Mojokerto Tahun 2017.

\begin{tabular}{|c|c|c|c|c|c|c|}
\hline \multirow{3}{*}{$\begin{array}{c}\text { Sanit } \\
\text { asi } \\
\text { Fisik } \\
\text { Rum } \\
\text { ah } \\
\end{array}$} & \multicolumn{4}{|c|}{ Kasus ISPA } & \multirow{2}{*}{\multicolumn{2}{|c|}{ Total }} \\
\hline & \multicolumn{2}{|c|}{ Ya } & \multicolumn{2}{|c|}{ Tidak } & & \\
\hline & $\mathbf{n}$ & $\%$ & $\mathbf{n}$ & $\%$ & $\mathbf{n}$ & $\%$ \\
\hline $\begin{array}{l}\text { Baik } \\
(76- \\
100)\end{array}$ & 4 & 8,0 & 5 & 10,0 & 9 & 18,0 \\
\hline $\begin{array}{l}\text { Cuku } \\
\text { p (56- } \\
75)\end{array}$ & 13 & 26,0 & 6 & 12,0 & 19 & 38,0 \\
\hline $\begin{array}{l}\text { Kura } \\
\text { ng }(0- \\
55)\end{array}$ & 19 & 38,0 & 3 & 6,0 & 22 & 44,0 \\
\hline Total & 36 & 72,0 & 14 & 28,0 & 50 & 100,0 \\
\hline \multicolumn{7}{|c|}{ p-value $=0,015<\alpha$} \\
\hline
\end{tabular}

Hasil tabulasi silang menunjukkan kecenderungan apabila sanitasi fisik rumah semakin baik maka jumlah kasus ISPA menurun, demikian sebaliknya. Hasil uji statistik regresi logistik menyatakan bahwa $p=0,015$ dimana $p$ kurang dari 0,05 ( $p$ kurang dari $\alpha$ ), yang artinya terdapat hubungan signifikan antara sanitasi fisik rumah dengan kasus ISPA pada anak balita di Desa Tumapel Kabupaten Mojokerto. 


\section{PEMBAHASAN}

\section{Hubungan antara karakteristik dengan kasus ISPA pada anak balita di Desa Tumapel Kabupaten Mojokerto tahun 2017}

Hasil penelitian mengenai karakteristik responden dengan kasus ISPA pada anak balita di Desa Tumapel menunjukkan bahwa, dari 5 sub variabel karakteristik anak balita yang terdiri dari umur, jenis kelamin, imunisasi, ASI eksklusif, dan status gizi yang memiliki hubungan signifikan dengan kasus ISPA di Desa Tumapel Kabupaten Mojokerto hanya umur. Hal ini sesuai dengan penelitian Iskandar, dkk (2015) bahwa terdapat hubungan antara umur dengan kasus ISPA pada anak balita di Rumah Sakit Umum Nurhayati Kabupaten Garut. Tetapi hal ini tidak sesuai dengan penelitian Fattah (2013) yang menyatakan bahwa tidak terdapat hubungan antar umur dengan kasus ISPA pada anak balita di Puskesmas Barugia Kabupaten Kepulauan Selayar.

Hasil penelitian sub variabel karakteristik anak balita yaitu jenis kelamin, imunisasi, ASI eksklusif, dan status gizi diperoleh bahwa nilai $\mathrm{p}$ lebih dari $\alpha$. Dari empat sub variabel tersebut tidak ada hubungan signifikan dengan kasus ISPA pada anak balita di Desa Tumapel Kabupaten Mojokerto. Hasil ini sesuai dengan penelitian Diaz (2012) bahwa antara karakteristik imunisasi dan status gizi tidak ada hubungan dengan kasus ISPA pada anak balita di Puskesmas Kecamatan Taman Sari Jakarta Barat. Hasil analisis ini tidak sesuai dengan penelitian Ranantha, dkk (2012) yang menyatakan bahwa terdapat hubungan antara karakteristik jenis kelamin dengan kasus ISPA pada anak balita. Anak balita berjenis kelamin laki-laki lebih berisiko terkena ISPA 5,641 kali dibandingkan dengan anak balita berjenis kelamin perempuan. Penelitian Iskandar, dkk (2015) bahwa terdapat hubungan signifikan antara jenis kelamin dengan kasus ISPA pada anak balita. Anak balita berjenis kelamin laki-laki lebih berisiko terkena ISPA 2,761 kali dibandingkan dengan anak balita berjenis kelamin perempuan.

Hasil analisis hubungan status gizi dengan kasus ISPA pada anak balita tidak sesuai dengan penelitian Febrianto, dkk (2014) bahwa terdapat hubungan antara status gizi dengan kasus ISPA pada anak balita serta apabila status gizi anak balita kurang maka kasus terjadinya ISPA tinggi dan apabila status anak balita baik maka kasus terjadinya ISPA menurun. Penelitian Surdiman (2003) menyatakan bahwa terdapat hubungan antara status gizi dengan kasus ISPA pada anak balita. Anak balita dengan status gizi kurang lebih berisiko menderita pneumonia 3,3 kali dibandingkan dengan anak balita dengan status gizi baik. Penelitian Ranantha, dkk (2012) menyatakan bahwa terdapat hubungan antara status gizi balita dengan kasus ISPA pada anak balita. Anak balita dengan status gizi kurang lebih berisiko terkena ISPA 10,947 kali dibandingkan dengan anak balita dengan status gizi baik.

Hasil analisis hubungan status imunisasi dengan kasus ISPA pada anak balita tidak sesuai dengan penelitian Rasyid (2013) yang menyatakan bahwa status imunisasi anak balita berhubungan dengan kasus ISPA pada anak balita. Anak balita dengan status imunisasi tidak lengkap berisiko terkena ISPA 1,636 kali dibandingkan anak balita dengan status imunisasi lengkap. Penelitian Adelina (2014) menyatakan bahwa terdapat hubungan bermakna antara status imunisasi anak balita dengan kasus ISPA pada anak balita. Anak balita dengan status imunisasi tidak lengkap berisiko terkena ISPA 0,253 kali dibandingkan anak balita dengan status imunisasi lengkap.

Hasil analisis hubungan pemberian ASI eksklusif dengan kasus ISPA pada anak balita tidak sesuai dengan penelitian Abbas, dkk (2010) dan Catiyas (2012) yang menyatakan bahwa terdapat hubungan antara pemberian ASI eksklusif 
dengan kasus ISPA pada anak balita. Penelitian Widarani, dkk (2010) menyatakan bahwa terdapat hubungan antara pemberian ASI eksklusif dengan kasus ISPA pada anak balita. Anak balita yang tidak mendapatkan ASI eksklusif lebih berisiko terkena ISPA 4,960 kali dibandingkan dengan anak balita yang mendapatkan ASI eksklusif. Penelitian Rasyid (2013) menyatakan bahwa terdapat hubungan antara ASI eksklusif dengan kasus ISPA pada anak balita. Anak balita yang tidak mendapatkan ASI eksklusif lebih berisiko terkena ISPA 1,994 kali dibandingkan anak balita yang mendapatkan ASI eksklusif.

\section{Hubungan antara sanitasi fisik rumah dengan kasus ISPA pada anak balita di Desa Tumapel Kabupaten Mojokerto tahun 2017}

Hasil penelitian mengenai sanitasi fisik rumah dengan kasus ISPA pada anak balita di Desa Tumapel menunjukkan bahwa ada hubungan signifikan antara sanitasi fisik rumah dengan kasus ISPA pada anak balita di Desa Tumapel Kabupaten Mojokerto.

Hal ini sesuai dengan penelitian Yusup (2005) yang menyatakan bahwa terdapat hubungan antara sanitasi fisik rumah dengan kasus ISPA pada anak balita di Kelurahan Penjaringan Sari Kecamatan Rungkut Kota Surabaya. Hasil penelitian Iswarini (2006) juga menyatakan bahwa ada hubungan antara kondisi fisik rumah dengan kasus ISPA pada anak balita di Kelurahan Manukan Kulon Kecamatan Tandes Kota Surabaya.

Sanitasi fisik rumah yang diteliti bervariasi, meski terdapat rumah yang masuk dalam kategori baik tetapi tidak ada yang mendapatkan skor penilaian memenuhi syarat sepenuhnya dikarenakan terdapat konsentrasi $\mathrm{PM}_{2,5}$ yang melebihi ambang batas di dalam rumah. Peraturan Menteri Kesehatan no 1077 Tahun 2011 menyatakan bahwa di dalam rumah batas $\begin{array}{llll}\text { konsentrasi debu } & \mathrm{PM}_{2,5} \quad \text { yang }\end{array}$ diperbolehkan sebesar $35 \quad \mu \mathrm{g} / \mathrm{m}^{3}$. Konsentrasi $\mathrm{PM}_{2,5}$ yang melebihi batas yang diperbolehkan dalam seluruh rumah, maka anak balita yang berada di dalam rumah berisiko terkena penyakit ISPA.

Rumah anak balita yang termasuk dalam kategori kurang disebabkan karena sebagian besar hasil pengukuran suhu dan kelembapan udara yang tidak sesuai dengan Peraturan Menteri Kesehatan No 1077 Tahun 2011. Suhu nyaman di dalam rumah seharusnya berkisar antara $18^{\circ} \mathrm{C}$ $30^{\circ} \mathrm{C}$ dan kelembapan nyaman di dalam rumah berkisar antara 40\%-60\%. Suhu dan kelembapan dalam rumah yang tidak memenuhi syarat kesehatan dapat menjadi lingkungan yang tepat bagi pertumbuhan dan perkembangbiakan bakteri penyebab ISPA. Sebagian besar rumah responden untuk variabel luas ventilasi dan kepadatan hunian telah memenuhi syarat.

Sebagian besar rumah warga Desa Tumapel memang memiliki pekarangan rumah yang cukup luas berupa tanah. Pekarangan rumah yang masih berupa tanah memungkinkan tingginya debu $\left(\mathrm{PM}_{2,5}\right)$ di lingkungan rumah (Putri, 2017). Setiap rumah memiliki ventilasi yang cukup banyak sehingga cahaya alami dapat masuk ke dalam rumah. Ketika pengukuran pencahayaan lampu tidak dinyalakan di ruang tamu, pencahayaan di dalam ruang tamu sudah sesuai dengan Peraturan Menteri Kesehatan No 1077 Tahun 2011. Rumah responden berdiri di atas tanah yang relatif cukup luas. Hampir pada seluruh rumah yang diobservasi hampir seluruh rumah terdapat 2-3 ruang tempat tidur, sehingga kepadatan hunian di Desa Tumapel sebagian besar telah memenuhi syarat, dimana dalam 1 kamar tidur dihuni 2 orang dewasa dengan 1 balita.

Kesehatan perumahan dan lingkungan pemukiman adalah kondisi fisik, kimia, biologi di dalam rumah, lingkungan rumah dan perumahan yang memungkinkan penghuni mendapat derajat kesehatan yang optimal. Persyaratan kesehatan perumahan dan lingkungan 
pemukiman merupakan ketentuan teknis kesehatan yang wajib dipenuhi dalam rangka melindungi penguni dan masyarakat yang bermukim di perumahan dan atau masyarakat sekitar dari bahaya atau gangguan kesehatan. Persyaratan kesehatan perumahan yang meliputi persyaratan lingkungan pemukiman serta persyaratan rumah itu sendiri, sangat diperlukan karena pembangunan perumahan berpengaruh sangat besar terhadap peningkatan derajat kesehatan individu, keluarga, dan masyarakat (Keman, S. 2005).

\section{SIMPULAN}

Kesimpulan yang dapat ditarik adalah karakteristik umur anak balita dan sanitasi fisik rumah memiliki hubungan yang signifikan dengan kasus ISPA pada anak balita di Desa Tumapel Kabupaten Mojokerto.

Disarankan agar dilakukan upaya untuk meningkatkan daya tahan tubuh balita dengan memberikan makanan dengan menu gizi seimbang dan meningkatkan kesehatan lingkungan rumah yaitu dengan menutup ventilasi ketika siang dan sore hari untuk menurunkan konsentrasi $\mathrm{PM}_{2,5}$. Debu yang terdapat di pekarangan rumah tidak masuk ke dalam rumah melalui ventilasi. Hal ini diharapkan dapat menurunkan risiko terjadinya kasus ISPA pada anak balita di Desa Tumapel Kabupaten Mojokerto.

\section{DAFTAR PUSTAKA}

Abbas, P., dan Haryati, A., 2011. Hubungan pemberian ASI eksklusif dengan kejadian Infeksi Saluran Pernapasan Akut (ISPA) pada balita. Semarang: Fakultas Kedokteran Universitas Islam Sultan Agung.

Adelina, B., 2014. Hubungan status imunisasi dengan Infeksi Saluran Pernapasan Akut (ISPA) pada balita (1-5 tahun) di Puskesmas Teladan Medan. Medan: Fakultas Keperawatan Universitas Sumatera Utara.

Badan Penelitian dan Pengembangan Kesehatan Kementerian Kesehatan. 2013. Riset kesehatan dasar. Jakarta: Kementerian Kesehatan.

Catiyas, E., 2012. Faktor-faktor yang berhubungan dengan kejadian ISPA pada balita di wilayah Kecamatan Gomboong Kabupaten Kebumen Jawa Tengah. Skripsi. Depok: Fakultas Kesehatan Masyarakat Universitas Indonesia.

Environmental Protection Agency. 2017. EPA's Report on the Environment (ROE) indoor air quality.

Diaz, Y., 2012. Hubungan karakteristik balita dan lingkungan terhadap kasus penyakit ISPA pada balita di Puskesmas Kecamatan Taman Sari Jakarta Barat. Jakarta: Universitas Esa Unggul.

Dinas Kesehatan. 2015. Data pemeriksaan rumah sehat. Kabupaten Mojokerto.

Fattah, A., 2013. Hubungan umur dan status imunisasi terhadap kasus penyakit ISPA pada balita 0-5 tahun di Puskesmas Barugia Kabupaten Kepulauan Selayar. Riau: Akbid Mutiara Jaya Persada.

Febriyanto, W., Mahfoedz, I., Mulyanti., 2014. Status gizi berhubungan dengan kejadian ISPA pada balita di wilayah Kerja Puskesmas Wonosari I Kabupaten Gunungkidul. Jurnal Gizi dan Dietetik Indonesia. Yogyakarta: STIKES Alma Ata.

Iskandar, A., Tanuwijaya, S., and Yuniarti, L., 2015. Hubungan jenis kelamin dan usia anak satu tahun sampai 5 tahun dengan kejadian Infeksi Saluran Pernapasan Akut (ISPA). Jurnal. Bandung: Universitas Islam Bandung.

Iswarini, D., 2006. Hubungan antara kondisi fisik rumah, kebersihan 
rumah, kepadatan penghuni dan pencemaran udara dalam rumah dengan keluhan penyakit ISPA pada balita. Skripsi. Surabaya: Fakultas Kesehatan Masyarakat Universitas Airlangga.

Keman, S., 2005. Kesehatan perumahan dan lingkungan pemukiman. Surabaya: Kesehatan Lingkungan Fakultas Kesehatan Masyarakat Universitas Airlangga.

Lemeshow, S., Hosmer, D.W., Klar, J dan Lwanga, S.K., 1997. Besar sampel dalam penelitian kesehatan. Jogjakarta: Gajahmada university press.

Nugraheni, M., 2014. Hubungan status gizi dengan kejadian ISPA pada balita di Posyandu Dahlia Desa Tirtonirmolo Kasihan Bantul Yogyakarta. Yogyakarta: Sekolah Tinggi Ilmu Kesehatan Aisyiah.

Nursalam. 2013. Metode penelitian ilmu keperawatan: Pendekatan Praktis Edisi 3. Jakarta: Salemba Medika.

Notoatmodjo, S., 2010. Metode penelitian kesehatan. Jakarta: Rieneka Cipta.

Peraturan Menteri Kesehatan. 2011. Persyaratan kualitas udara dalam rumah no 1077. Republik Indonesia.

Putri, M. D. A., 2017. Hubungan sanitasi fisik rumah dan $\mathrm{PM}_{10}$ dengan kejadian ISPA pada anak balita di pemukiman sekitar lingkungan industri Desa Tumapel Kabupaten Mojokerto. Skripsi. Surabaya: Fakultas Kesehatan Masyarakat Universitas Airlangga.

Ranantha, R., Mahawati, E., Kriswiharsih, K., 2012. Hubungan antara karakteristik balita dengan kejadian ISPA pada balita Desa Gandon Kecamatan Kaloran Kabupaten Temanggung. Semarang: Universitas Dian Nuswantoro.

Rasyid, Z., 2013. Faktor-faktor yang berhubungan dengan kejadian pneumonia anak balita di RSUD Bangkinang Kabupaten Kampar. Pekanbaru: Fakultas Ilmu Kesehatan Masyarakat Universitas STIKes Hang Tuah.

Sudirman. 2003. Faktor lingkungan fisik rumah dan faktor risiko lainnya dengan kejadian pneumonia pada balita di Puskesmas Teluk Pucung Kota Bekasi Tahun 2003. Tesis. Depok: Fakultas Kesehatan Masyarakat Universitas Indonesia.

UNICEF/WHO. 2006. Pneumonia the forgotten killer of children.

Widoyono. 2011. Penyakit tropis: epidemiologi, penularan, pencegahan, dan pemberantasannya. Jakarta: Erlangga.

Widarani, N. dan Sumasari, N., 2010. Hubungan pemberian ASI eksklusif dengan kejadian ISPA pada balita. Bali: Fakultas Ilmu Kesehatan Masyarakat Universitas Udayana.

Widia, L., 2017. Hubugan antara status gizi dengan kejadian ISPA pada balita. Jurnal Darul Azhar Indonesia.

Yusup, A., 2005. Hubungan sanitasi rumah secara fisik dengan kejadian ISPA pada balita. Surabaya: Jurnal Kesehatan Lingkungan Universitas Airlangga. 